ESJ Social Sciences

\title{
Financial Behaviour and Retirement Planning in Kenya, Assessing the Role of Self-Control Bias
}

\author{
Cynthia Stella Waga \\ Jomo Kenyatta University of Agriculture and Technology, Nairobi, Kenya \\ Prof. Florence Memba \\ Jomo Kenyatta University of Agriculture and Technology. \\ Dean, School of Business and Entrepreneurship, Nairobi, Kenya \\ Dr. Jane Muriithi \\ Africa International University, Karen, Nairobi, Kenya
}

Doi:10.19044/esj.2021.v17n23p348

Submitted: 12 July 2021

Accepted: 22 July 2021

Published: 31 July 2021
Copyright 2021 Author(s)

Under Creative Commons BY-NC-ND

4.0 OPEN ACCESS

Cite As:

Waga C.S., Memba F. \& Muriithi J. (2021). Financial Behaviour and Retirement Planning in Kenya, Assessing the Role of Self-Control Bias. European Scientific Journal, ESJ, 17(23), 348. https://doi.org/10.19044/esj.2021.v17n23p348

\begin{abstract}
The shift towards defined contribution schemes is forcing employees to take personal responsibility for securing their future through intentional retirement savings. Financial behavior may have a significant bearing on whether employees meet their contributory retirement obligations while avoiding financial distress. Utilising a cross-sectional research design and data from pension scheme members in Kenya, the study evaluates the interaction of self-control bias. The binary logistic regression results showed that financially disciplined individuals are 1.634 times more likely to plan comprehensively for their retirement, while the interaction results suggest that individuals with self-control bias are 0.502 times less likely to be comprehensive retirement planners even if they are already financially disciplined. The findings imply that financial discipline coupled with selfcontrol is necessary for retirement planning. The use of behavioral change interventions is recommended in financial education initiatives in order to inculcate both desirable financial behavior and self-control attributes in planning for retirement.
\end{abstract}


Keywords: Financial Behaviour, Self-Control Bias, Retirement Planning, Pension

\section{Introduction}

Employees in many countries have increasingly been asked to take on a remarkable role in planning for their retirement. This is because most governments and employers are moving from defined benefit pensions to defined contribution schemes to reduce their pension burden. The development of technology has led to rapid changes in the financial markets, which has brought about new and more complex financial products being available in these markets. As a result, employees face a wide range of financial products and economic decisions to make, implying that it is more important for them to improve their economic know-how (Lusardi \& Mitchell, 2019). This also implies that employees need to adopt responsible financial behavior to meet the contributory retirement obligations while avoiding financial distress.

Financial behavior has been simply defined by Baker and Nofsinger (2010) as how human beings actually behave or act in a financial setting. Mudzingiri et al. (2018) posit that financial behavior plays an essential part in influencing the welfare of individuals at a household level and at a national level. Responsible financial behavior is beneficial to both an individual and the society at large; it will improve the personal financial well-being of the individual and contribute to society by reducing the instances of problematic debt and other financial problems that may take a toll on the mental health of individuals further leading to lower productivity at work. (Gathergood, 2012, van Raaij, 2016).

Akben-Selcuk (2015) identified some attributes of financial behavior among students to comprise timely payment of bills, creating personal budgets and saving for the future. Likewise, van Raaij (2016) identifies ten responsible and sustainable financial behavior, namely: spending based on income; avoiding impulsive purchases by making deliberate decisions; carefully choosing financial products; seeking help from competitive financial advisers or planners; keeping a financial buffer for unforeseen expenditures; having enough discretionary earnings for day to day expenses; paying bills in time; taking insurance for income decline; taking risks that one can easily manage with credits and investments and finally taking into account the possible future outcomes.

\subsection{Self-control bias and financial behavior}

The role of behavioral economics in influencing the process of decision-making has recently gained acceptance. Baker and Ricciardi (2014) construe that individuals make mistakes while making important financial 
decisions hence contradicting the traditional theories of rationality, this is exhibited by behavioral biases. Behavioral biases are systematic errors committed by individuals when they act irrationally, and one such bias is selfcontrol bias. Pompian (2006) defines self-control bias as a human behavioral weakness that makes individuals consume now at the expense of saving for tomorrow, where there is a struggle between one's overarching goals and failure to act towards these goals caused by insufficient self-discipline. Pompian (2006) further posits that money spending is one of the areas in which individuals exhibit a lack of self-control. The fact that self-control bias can cause a person to concentrate on today at the expense of tomorrow can be dangerous to one's wealth, especially when one retires. This bias may also cause individuals not to plan appropriately for their retirement (in the long term ) even if one has the requisite financial discipline in the short term.

O'Donoghue and Rabin (2001) asserts that self-control problems are universal, for instance, when an individual may intend to behave in one way but end up behaving in another. This may be caused by the pursuit of immediate gratification while ignoring the long-term consequences. To secure their long-term financial well-being, an individual must practice self-restraint in the short term (Howlett, Kees, \& Kemp, 2008). Several studies have linked self-control with various financial behaviors. Gathergood (2012) found that individuals with self-control problems are more likely to suffer from unforeseen expenses and credit withdrawals, leading to over-indebtedness. At the same time, Achtziger et al. (2015) report that individuals with low selfcontrol are more likely to engage in compulsive purchases.

In regards to wealth accumulation, Biljanova and Palligkinis (2015) also link self-control problems with low wealth accumulation. They posit that individuals who do not plan and monitor their finances report lower wealth accumulation. Additionally, Choi et al. (2011) established that individuals with less self-control are less likely to have enough savings for their retirement. However, Ballinger et al. (2011) report contradictory findings that self-control and other different kinds of measured impulsive behavior did not affect savings behavior. Xiao et al. (2006) also found that giving up one's current spending by engaging in flexible spending plans was negatively associated with their financial satisfaction levels. Therefore, this implies inconclusive results on the relationship between self-control and financial behavior, which may be context-specific.

The objectives of this paper are to: (i) assess the importance of financial behavior (financial discipline) on retirement planning and (ii) examine the moderating effect of self-control on the relationship between financial behavior and retirement planning. The results show that although financial discipline increases the likelihood of comprehensive retirement planning, individuals with self-control problems (self-control bias) are more 
unlikely to be comprehensive retirement planners even if they are already financially disciplined.

\subsection{Retirement Planning in Kenya}

Kenya's Vision 2030 includes pension funds as a crucial pillar in delivering economic growth and greater advancements in the financial markets. The Kenyan pension system structure is divided into four categories: the National Social Security Fund (NSSF), the Civil Service Pension Scheme; Occupational retirement schemes, and Individual Retirement Pensions. (RBA, 2019)

The National Social Security Fund (NSSF) is a compulsory scheme where all employers and employees governed by the Employment Act 2007 must make monthly contributions. It is a provident fund regulated by the NSSF Act 1978, which was later reviewed by the NSSF Act 2013 enactment. Employers normally institute occupational retirement benefits schemes voluntarily to benefit their permanent employees. The schemes can either be a pension fund or provident fund funded through contributions from both the employer and employee. On the other hand, Individual retirement benefits schemes are established by corporate institutions and target the general public. They provide a retirement savings platform for those employed but without established occupational schemes, self-employed individuals, and those wishing to make additional voluntary contributions. The civil service pension scheme is established by an Act of Parliament for all civil servants, disciplined forces and teachers working for the government. It is a Pay As You Go nonfunded, with members not contributing as it is funded from government revenue collections.

According to the Financial Stability Report of 2019, the current pension coverage stands at $22 \%$ of the total labor force in 2019 compared to $20 \%$ in 2018, showing a slight increase in coverage. Despite this increment in the coverage level, this level is still low as it implies that $88 \%$ of those employed are not saving for retirement. The 2020 Economic Survey reports that $82.9 \%$ of the total workforce employed in 2019 were from the informal workforce, where pension coverage is still very low (IOPS, 2018).

Despite the enactment of new legislation on early withdrawals in Kenya, employees have still opted to withdraw their pension savings from schemes upon changing jobs or leaving employment before attaining their retirement age. This early access of benefits is self-defeating and short-sighted as it reduces the amount that retirees get as a pension upon retirement (Were, 2011). Lusardi and Mitchell (2009) found that most retirees live miserable lives upon retirement due to reduced income and lack of forward planning for their retirement phase in life, caused by undesirable financial behavior exhibited during the pre-retirement phase. The lack of self-control during the 
productive years among many only makes the problem worse. Thaler and Bernartzi (2004) emphasize that the rapid change from defined benefit plans to defined contribution plans calls for self-control to sustain savings for retirement.

\section{Literature Review}

The life-cycle hypothesis has been proposed as the theory that explains retirement savings over an individual's lifespan. Modigliani and Brumberg (1950) posit that individuals plan their consumption and savings behavior over their life cycle. They further hypothesize that individuals make rational financial decisions and maximize their lifetime utility by smoothening their consumption over their entire lifetimes by accumulating wealth when young and are earning and dis-saving when they are retired.

On the contrary, the behavioral life-cycle hypothesis $(\mathrm{BLCH})$ posits that individuals are not always rational and sometimes will deviate from the standard economic model because they will find it difficult to avoid cognitive and emotional errors and balance the need for saving for tomorrow with the need for spending now. (Statman, 2017). Shefrin and Thaler developed this Behavioural life-cycle hypothesis in 1988. The model incorporated Selfcontrol, mental accounting, and framing to enrich the life-cycle theory. Shefrin (2002) further suggested that individuals lack the requisite willpower to make long-term retirement savings plans because they have limited mental skills required to solve multi-period retirement saving problems. Madrian and Shea (2001) additionally cite inertia and procrastination in financial decisionmaking as the main behavioral challenges to retirement savings. Other factors that can inhibit efficient decision making are heuristics, decision framing and loss aversion (Hede, 2012)

Hastings and Mitchell (2011), in their quest to understand why individuals fail to optimize their financial decision, used experimental evidence from Chile in southern American, analyzed two main reasons: one is that individuals are financially illiterate and secondly, that individuals are impatient or biased towards the present, implying that they choose gratification now over future, higher payoffs. The researchers found impatience to be a strong predictor of retirement saving while financial literacy to be associated with accumulated retirement saving, although it appeared to be a weaker predictor in framing investment decisions. Therefore, they posit that policymakers interested in enhancing retirement well-being should address behavioral shortcomings that may impede long-term financial planning and decision-making.

Previous research has linked self-control to desirable financial behavior. For instance, Sahi (2017) explored different psychological biases by investors to see whether they are related to financial satisfaction. The study 
results reported a positive and significant relationship between self-control bias and financial satisfaction, implying that investors who had the tendency of forgoing their present consumption for the sake of saving for the future and exercised some degree of self-control were more disposed towards being financially satisfied.

Kim et al. (2016), while examining self-control problems of U.S households and their effect on household's retirement preparedness based on the Behavioural life-cycle hypothesis, found that a considerable proportion of U.S households had self-control problems in loan payment and savings decisions. They also put forward that households with loan repayment and self-control problems were less likely to be adequately prepared for retirement. They further suggest the use of self-control practices to improve retirement preparedness.

Consequently, Stromback et al (2017) attempt to understand how people make financial decisions investigated the psychological characteristics that influence individuals' financial behavior and financial well-being. Their study explored individual differences in self-control and other emotional factors on financial behavior and financial well-being. They found that people with good self-control were inclined to save money from their monthly salary, showed positive financial behavior, were less anxious about financial matters, and felt more confident in their current and future financial situation.

\section{Methodology}

To achieve its objectives, this study used a population of contributory pension schemes members as recorded by the RBA at the end of 2018, including members of the occupational retirement schemes, NSSF and individual pension schemes in Kenya. According to the RBA (2019), there were 1172 occupational pension schemes registered as at the end of December 2018 with total membership of 540,487. The NSSF has the largest membership of 2,629,689 who also incorporated the occupational scheme members, while the individual pension schemes were 45 with a total membership of 199,024 . This gives a total of 2,828,713 as the total population of the study.

Two main strata were identified; members of the NSSF schemes and members of occupational schemes as the first strata and members of individual pension schemes as second strata; this is because the first serve employees in the formal sector and the latter mostly serve employees in the informal sector. Since the population variance with respect to the dependent variable is unknown, the sample size estimation follows the recommendations by Bartlett et al. (2001).

$$
n o=\frac{t^{2} p(1-p)}{e^{2}}
$$


Where; $\mathrm{n}_{0}=$ defined sample size, $\mathrm{t}=\mathrm{t}-$ value at $0.05, \mathrm{t}=2.58, \mathrm{p}=$ proportion of those who have planned for retirement, $1-\mathrm{p}=$ proportion of those who have not planned for retirement and e is margin error (taken to be 0.05 )

$$
n o=\frac{2.58^{2}(0.2)(0.8)}{0.05^{2}}=410
$$

The sample size was then chosen proportionately, according to the total membership of the different retirement benefit schemes. A logistic regression analysis was preferred because the dependent variable is binary, taking the value of 1 for comprehensive retirement planners and 0 for those who are basic retirement planners. The basic planners will be pension scheme members who will have been automatically enrolled to a pension scheme with low contributions, in this case, NSSF. In contrast, comprehensive planners will be pension scheme members who are automatically enrolled into a scheme, but that have a high contribution, as well as those scheme members who have taken up an active role in enrolling themselves into a pension scheme. Both theoretical and empirical results suggest that when the response variable is binary, the shape of the response function is either as a tilted $\mathrm{S}$ or as a reverse tilted S. A multiple logistic regression shown in equation five was used to enable the study to capture the non-linear relationship between the variables. The equation incorporated demographics and other variables that influence retirement planning based on previous studies. These are financial awareness, financial knowledge and self-control. (Lusardi \& Mitchell, 2019, OECD, 2016, Kim et al 2016)

$$
\begin{gathered}
\operatorname{In}(\text { odds })=\operatorname{In}\left(\frac{p}{1-P}\right)=\operatorname{Logit}(p) \\
\operatorname{Logit}(P)=\ln \left(\frac{P}{1-P}\right)=\beta_{0}+\beta_{1} X+\beta_{2} F B+\beta_{3} F K+\beta_{4} F A+\varepsilon \\
\operatorname{Logit}(P)=\beta_{0}+\beta_{1} X+\beta_{2} F B+\beta_{3} F K+\beta_{4} F A+\beta_{5} S C B+\beta_{6} F B * S C B+
\end{gathered}
$$

Where Logit (p) is Probability of being a comprehensive planner, $\mathrm{X}$ includes all control variables (age, income level and education level), FB is financial behavior, FK is financial knowledge, FA is financial awareness and $\mathrm{SCB}$ is self-control bias.

\subsection{Measurements of Variables}

The Certified Financial Planners Board of standards and Consumer Federation of America (2013) in their Household Financial Planning Behaviour Survey, classified households' financial planning profiles into four main distinct categories representing the different levels of financial planning. The four groups are comprehensive planners, basic planners, limited planners and non-planners. This study has utilized the certified financial planners' board of standards approach of classification but will only use two main 
categories; basic planners and comprehensive planners. This is because the scope of the study is individuals that are already in pension schemes and so they are already enrolled in a savings plan. The basic planners will be pension scheme members who will have been automatically enrolled to a scheme with low contributions, while comprehensive planners will be pension scheme members who are automatically enrolled into a scheme but that has a high contribution ratio, as well as those scheme members who have taken up an active role in enrolling themselves into a pension scheme.

Financial behavior was captured by using a variety of likert scale questions to determine behaviour such as thinking before making a purchase, paying bills on time and budgeting, saving and borrowing to make ends meet. Self-control bias was also measured using Likert scale questions based on individuals' attitudes towards long-term savings versus spending today. These questions were derived from OECD/INFE framework of measuring financial literacy.

\section{Discussion of Results \\ 4.1 Descriptive Statistics}

Table 1 represents the results from the classification of pension scheme members as either basic planners or comprehensive planners. This was based on the category of pension plan an individual had. Those with the NSSF scheme members who their employer automatically registered into the scheme were classified as basic planners. In contrast, those who had an individual pension plan and occupational plans beyond the NSSF were classified as comprehensive planners. Individuals who had taken the initiative to register themselves with a pension plan, be it NSSF or Individual pension plans, were also classified as comprehensive planners as they exhibited the attribute of actively saving for their retirement.

Table 1: Descriptive results of Retirement planning

\begin{tabular}{cccccc}
\hline & & Frequency & Percent & Valid Percent & $\begin{array}{c}\text { Cumulative } \\
\text { Percent }\end{array}$ \\
\hline \multirow{3}{*}{ Valid } & basic planner & 157 & 47.3 & 47.3 & 47.3 \\
& Comprehensive Planner & 175 & 52.7 & 52.7 & 100.0 \\
& Total & 332 & 100.0 & 100.0 & \\
\hline
\end{tabular}

From Table 1, 47.3\% were classified as basic planners, while $52.7 \%$ were classified as comprehensive planners. This is contrary to the result of the study by Githu \& Ngare (2014), who focused on the relationship between financial literacy and retirement planning in the informal sector, in their study the proportion of non-planners $(60 \%)$ were more than planners $(40 \%)$ among individuals in the informal sector. The main reason for the discrepancy could be because of the target groups, the current study focused on retirement 
scheme members who are obliged to save by virtue of being mostly in the formal sector, while the study by Githu \& Ngare (2014) focused on the informal sector employees who voluntarily save for retirement.

The study sought to examine the respondent's behavior that makes them financially resilient and, in a position to counter financial shocks. These behaviors include making considered purchases, paying bills on time, taking a close watch of personal financial affairs, setting long-term goals, setting monthly budgets, actively saving and investing, gathering information before purchasing financial products, and not borrowing to make ends meet.

Table 2: Financial Behaviour Descriptive Statistics

\begin{tabular}{|c|c|c|c|c|}
\hline & $\begin{array}{c}\text { Mea } \\
\mathrm{n}\end{array}$ & Median & Mode & Std dev \\
\hline $\begin{array}{c}\text { Before I buy something, I carefully consider whether I can } \\
\text { afford it }\end{array}$ & 4.09 & 4.00 & 4.00 & 1.03 \\
\hline I pay my bills on time & 3.77 & 4.00 & 4.00 & 1.03 \\
\hline I keep a close personal watch on my financial affairs & 3.84 & 4.00 & 4.00 & 1.05 \\
\hline I set long term financial goals and strive to achieve them & 3.72 & 4.00 & 4.00 & 1.02 \\
\hline I prepare a monthly household budget and adhere to it. & 3.49 & 4.00 & 4.00 & 1.14 \\
\hline $\begin{array}{l}\text { I have been actively saving or buying investments in the } \\
\text { past } 12 \text { months }\end{array}$ & 3.31 & 4.00 & 4.00 & 1.21 \\
\hline $\begin{array}{l}\text { I shop around and gather information before purchasing a } \\
\text { financial product }\end{array}$ & 3.77 & 4.00 & 4.00 & 1.13 \\
\hline I do not borrow to make ends meet & 3.28 & 4.00 & 4.00 & 1.39 \\
\hline
\end{tabular}

Table 2 presents the relevant results on a scale of 1 to 5 (where $1=$ strongly disagree and strongly agree $=5$ ). The means, mode, median and standard deviations were recorded as above. The statements "before I buy something, I carefully consider whether I can afford it" had a mean of 4.0934, median of 4, mode of 4 and standard deviation of 1.02856. While the rest of the statements "I pay my bills on time," "I keep a close personal watch on my financial affairs," "I set long term financial goals and strive to achieve them, "I prepare a monthly household budget and adhere to it," "I have been actively saving or buying investments in the past 12 months", "I shop around and gather information before purchasing a financial product," "I do not have to borrow to make ends meet" also had a median of 4 (Agree) and a mode of 4 (Agree). The implication is that, on average, the pension scheme members tend towards responsible financial behavior as they tend towards agreeing (4) to all the behavioral tendencies.

The short term and long-term financial situations of individuals are shaped by their actions and behavior. It is therefore imperative to evaluate the behavioral tendencies of individuals both in the short term and long term. Table 3 reports the proportion of pension scheme members who exhibited responsible financial behavior under the different categories. 
Table 3: Financial Behaviour Frequencies

\begin{tabular}{|c|c|c|c|}
\hline & \multicolumn{2}{|c|}{ Responses } & \multirow{2}{*}{$\begin{array}{l}\text { Percent of } \\
\text { Cases }\end{array}$} \\
\hline & $\mathrm{N}$ & Percent & \\
\hline Carefully consider purchase & 272 & $15.3 \%$ & $85.5 \%$ \\
\hline Pays bills on time & 236 & $13.3 \%$ & $74.2 \%$ \\
\hline Watch financial affairs & 239 & $13.5 \%$ & $75.2 \%$ \\
\hline Sets Long Term goals & 229 & $12.9 \%$ & $72.0 \%$ \\
\hline Budgeting & 199 & $11.2 \%$ & $62.6 \%$ \\
\hline Actively saves & 182 & $10.3 \%$ & $57.2 \%$ \\
\hline Gathers information before purchasing & 241 & $13.6 \%$ & $75.8 \%$ \\
\hline Don't borrow to make ends meet & 174 & $9.8 \%$ & $54.7 \%$ \\
\hline
\end{tabular}

a. Dichotomy group tabulated at value 1 .

From Table 3, a majority of the pension scheme members, $75.8 \%$ reported that they shop around and gather information before purchasing a financial product, while $85.5 \%$ carefully considered whether they can afford an item before making a purchase. This is a good indication of a thorough decision-making process by the scheme members. $74.2 \%$ of members also reported that they promptly pay their bills while watching their financial affairs closely.

The descriptive statistics also show that $62.6 \%$ of pension scheme members have a monthly budget in place and adhere to it, while $72 \%$ report that they set long-term financial goals and strive to achieve them. Goal setting and written budgets are vital tools for money management and are key components in financial literacy, as identified in the G20/OECD INFE core competencies framework on financial literacy.

Notably, 5 out of 10 scheme members have been actively saving and buying investment products in the 12 months preceding the survey. Active saving is an important competence as individuals who exhibit this behavior easily smoothen their income and expenditure flows and are more likely to be resilient to financial shocks and better meet their financial goals. (OECD, 2016).

A cross-tabulation of retirement planning and the different behavioral tendencies resulted in the following chi-square tabulation showing the level of association. 
Table 4: Pearson Chi-Square Tests

\begin{tabular}{|c|c|c|}
\hline & & Retirement planning \\
\hline & Chi-square & 1.803 \\
\hline \multirow[t]{3}{*}{ Carefully consider purchase } & Df & 4 \\
\hline & Sig. & .772 \\
\hline & Chi-square & 18.021 \\
\hline \multirow[t]{3}{*}{ Pay bills on time } & Df & 4 \\
\hline & Sig. & $.001^{*}, \mathrm{~b}$ \\
\hline & Chi-square & 13.765 \\
\hline \multirow[t]{3}{*}{ close watch of financial } & Df & 4 \\
\hline & Sig. & $.008^{*}, \mathrm{~b}$ \\
\hline & Chi-square & 3.325 \\
\hline \multirow[t]{3}{*}{ set long term goals } & Df & 4 \\
\hline & Sig. & $.505^{\mathrm{b}}$ \\
\hline & Chi-square & 9.838 \\
\hline \multirow[t]{3}{*}{ set monthly budget } & Df & 4 \\
\hline & Sig. & $.043^{*}$ \\
\hline & Chi-square & 11.889 \\
\hline \multirow[t]{2}{*}{ Actively saves and invests } & Df & 4 \\
\hline & Sig. & $.018^{*}$ \\
\hline \multirow{4}{*}{$\begin{array}{l}\text { Gather information before } \\
\text { purchasing financial products }\end{array}$} & Chi-square & 12.151 \\
\hline & Df & 4 \\
\hline & Sig. & $.016^{*}$ \\
\hline & Chi-square & 9.663 \\
\hline \multirow[t]{2}{*}{ Don't borrow to make ends meet } & Df & 4 \\
\hline & Sig. & $.046^{*}$ \\
\hline
\end{tabular}

Results are based on nonempty rows and columns in each innermost subtable. *. The Chi-square statistic is significant at the .05 level.

Financial behavioral tendencies that have a significant association with retirement planning are; paying bills on time, closely watching ones financial affairs, setting and adhering to monthly budgets, actively saving and investing, gathering information before purchasing financial products and refraining from borrowing to make ends meet, as the reported p-values were all less than 0.05. these findings are consistent with Hira et al. (2009) who found that individuals who use more financial information sources; those who started investing early in life and those who had been active investors in the past 12 months were more likely to own an IRA (individual retirement account). Carefully considering whether one can afford an item before purchasing and setting long-term financial goals was found not to be significant. 


\subsection{Empirical Results}

After exploring the data, this section presents the empirical results from the estimation of the multiple logistic regression presented in equation 5 .

\subsubsection{The Influence of Financial Behavior on Retirement Planning in Kenya}

Table 5 presents the logistic regression results of the influence of financial behavior and other variables identified by previous studies on retirement planning. Model 1 reports the logistic regression results of elements of financial literacy; financial knowledge, financial awareness and financial behavior. Model 2 has the same variables as in Model 1 but also incorporates demographic factors. Model 3 incorporates self-control bias, which is the emotional bias aspect of finding satisfaction in spending money today rather than saving it for the future, thereby incorporating the aspect of being myopic, commonly referred to as self-control bias. Model 4 aims to achieve parsimony from Model 3 and drops the variables that are not statistically significant in the Model 3 to improve the model's explanatory power.

Table 5: Influence of Financial Behavior on Retirement Planning in Kenya

\begin{tabular}{|c|c|c|c|c|}
\hline Variables & Model 1 & Model 2 & Model 3 & Model 4 \\
\hline Income & & $1.871^{*}(0.000)$ & $1.769^{*}(0.000)$ & $1.960^{*}(0.000)$ \\
Age & & $1.232(0.151)$ & $1.204(0.213)$ & \\
Education level & & $1.117(0.389)$ & $1.147(0.310)$ & \\
Financial behaviour & $1.416^{*}(0.004)$ & $1.184(0.186)$ & $1.588^{* *}(0.008)^{*}$ & $1.634(0.005)$ \\
Financial knowledge & $1.206^{*}(0.104)$ & $1.196(0.147)$ & $1.179(0.193)$ & \\
Financial awareness & $1.769^{*}(0.000)$ & $1.589^{*}(0.001)$ & $1.614^{*}(0.000)$ & $1.629^{*}(0.000)$ \\
Self-control bias & & & $1.603^{* *}(0.086)$ & $1.606^{* *}(0.070)$ \\
Financial behavior*self-control & & & $0.511(0.019)^{*}$ & $0.502(0.015)$ \\
bias & & & & \\
Constant & 1.122 & $1.165(0.216)$ & $0.924(0.623)$ & $0.925(0.626)$ \\
Observations & 332 & 332 & 332 & 332 \\
Pseudo R2 & 0.1054 & 0.1489 & 0.1696 & 0.1607 \\
\hline
\end{tabular}

*denotes statistically significant at 5\% and ** denotes statistical significance at $10 \%$.

Figures in parenthesis are the p-values.

Model 1 results show that financial behavior is statistically significant in explaining retirement planning. Pension scheme members who exhibited responsible financial behavior were 1.416 times more likely to plan for their retirement comprehensively than those who lacked this trait. This result is in tandem with previous studies that found a statistically significant causal relationship between financial behavior and other variables related to managing personal finance. For instance, Sundindra and Naidu (2018) found a significant positive impact of financial behavior on decision-making in a sample of 378 working women serving in information technology services in 
Bengaluru, India. Similarly, Gutter and Copur (2011), in their study among college students, reported that budgeting, savings, risky credit card behaviors, and compulsive buying were significantly related to the students' financial well-being.

Financial awareness was also significant at a 5\% level of significance, while financial knowledge was significant at $10 \%$ significance level. Pension scheme members who were aware of the financial products and institutions were 1.769 more likely to plan for retirement than those who are not comprehensively aware. Pension scheme members who possessed the attribute of financial knowledge were 1.206 times or $20.6 \%$ more likely to be comprehensive planners than those who lacked the knowledge.

The findings in Model 2 indicate that when demographic factors are incorporated, pension scheme members who are financially disciplined or exhibit responsible financial behavior are 1.18 times more likely to comprehensively plan for their retirement than those that are not financially disciplined. However, the p-value of the Wald test is 0.186 , which indicates that financial behavior is not a significant variable in explaining retirement planning when demographic variables are considered. The Pseudo R-squared also increases from $10 \%$ to $14 \%$, implying that the demographic factors contribute significantly to explaining the variations in retirement planning.

With the introduction of self-control bias in Model 3, there is a change in the p-value of the financial behavior variable from 0.186 as obtained in Model 2 to 0.008 , showing a move from insignificance to being statistically significant. The odds ratio (of financial behavior) also increases from 1.184 to 1.588 , implying that when we control for self-control bias, members who exhibited responsible financial behavior were 1.588 times more likely to comprehensively plan for their retirement than those who lacked this trait. The odds ratio of the interaction between financial behavior and self-control bias is 0.51 , implying that pension scheme members who exhibit responsible financial behavior but are myopic (with a self-control bias) are 0.51 times less likely to plan comprehensively for their retirement than those who are disciplined and are self-controlled. This finding is important and shows that financial discipline in itself is not important if members are myopic and have no self-control and is similar to the findings of Kim et al. (2016). The latter found that individuals with saving decision self-control problems were more likely to have insufficient savings for their retirement. Likewise, Stromback et al. (2017) also pointed out that individuals who exercised self-control are inclined to save money from their monthly salary and feel more confident in their current and future financial situation. This finding suggests that responsible financial behavior alone is not sufficient for one to plan comprehensively. Still, self-control coupled with responsible financial behavior is requisite traits for one to plan for their retirement comprehensively. 
The more parsimonious Model 4 shows that income and financial awareness are significant in explaining retirement planning. In contrast, age, education level and financial knowledge do not explain financial planning when we control for self-selection. For a pension scheme member who is financially aware of the existing financial products and institutions, the odds to comprehensively plan for their retirement is 1.6 times more than those not aware. Furthermore, pension scheme members who earn higher incomes are 1.6 times more likely to be comprehensive planners than their counterparts who are low-income earners.

\subsubsection{The Influence of Financial Behavior on Voluntary Retirement Planning in Kenya}

In this subsection, the results are presented for pension scheme members who have taken an active role in planning for their retirement, otherwise called voluntary planners. The pension scheme members included here are those who had taken the initiative to enroll themselves in a pension scheme without automatically being enrolled by their employers and those employees with occupational pension schemes who had voluntarily added their pension savings, indicating intentionality in saving for retirement and increasing the amount of pension contributed for retirement.

Table 6: Logistic regression results for voluntary pension scheme members

\begin{tabular}{|c|c|c|c|}
\hline Variables & Model 5 & Model 6 & Model 7 \\
\hline Income & $1.171(0.284)$ & $1.158(0.327)$ & $1.266^{*}(0.063)$ \\
Age & $1.146(0.338)$ & $1.118(0.439)$ & \\
Education level & $1.113(0.442)$ & $1.157(0.310)$ & \\
Financial behaviour & $1.187(0.195)$ & $1.365^{* *}(0.083)$ & $1.375^{* *}(0.074)$ \\
Financial knowledge & $1.278^{* *}(0.067)$ & $1.251^{* *}(0.097)$ & $1.268^{* *}(0.077)$ \\
Financial awareness & $1.087(0.537)$ & $1.089(0.523)$ & \\
Self-control bias & & $1.565^{* *}(0.103)$ & $1.486(0.133)$ \\
Financial behavior*self-control & & $0.797(0.417)$ & $0.779(0.369)$ \\
& & & \\
ccocontrolcontrol bias & & & $0.332(0.000)$ \\
Constant & $0.382(0.000)$ & $0.316(0.000)$ & 332 \\
Observations & 332 & 332 & 0.0389 \\
Pseudo R2 & 0.0355 & 0.0440 & \\
\hline
\end{tabular}

*denotes statistically significant at 5\% and ** denotes statistical significance at $10 \%$. Figures in parenthesis are the p-values.

Model 5 indicates that financial knowledge is the only statistically significant variable at $10 \%$ significance level in explaining intentionality in retirement planning. Pension scheme members who understand the basic financial concepts are 1.278 times more likely to be intentional in planning for 
retirement than those who lack financial knowledge. The other variables, including financial awareness, financial behavior, age and income, are not statistically significant even at a $10 \%$ significance level.

The introduction of the self-control bias and its interaction with financial behavior in Model 6 has a moderating effect on the relationship between financial behavior and intentionality in retirement planning. Pension scheme members who had responsible financial behavior were 1.365 times more likely to actively plan for retirement by taking up individual pension schemes and implementing additional savings in their occupational pension schemes. Self-control bias was significant in improving the entire model from a pseudo $\mathrm{R}^{2}$ of 0.0355 to 0.0440 .

Model 7 results, on the other hand, indicate that income level, financial behavior and knowledge of basic financial concepts are significant in explaining intentionality in retirement planning at $10 \%$ significance level, while the interaction of self-control and financial behavior is not significant in explaining intentionality in retirement planning.

\section{Conclusions and Recommendations}

The increasing shift from defined benefit pensions towards defined contribution schemes has forced employees to adopt responsible financial behavior to meet the contributory retirement obligations while avoiding financial distress. However, financial discipline is not always common for many people. Most retirees in Kenya live miserable lives upon retirement due to the lack of forward planning for their retirement phase in life attributed to undesirable financial behavior exhibited during the pre-retirement phase. This lack of financial discipline and self-control during the productive years among many only makes the problem worse during retirement. This study assessed the importance of responsible financial behaviour on retirement planning and examined the moderating effect of self-control on the relationship between financial behavior and retirement planning.

Although empirical evidence shows that although responsible financial behaviour increases the likelihood of comprehensive retirement planning, this study concludes that self-control plays a $\mathrm{n}$ important role on pension scheme members in informing their decisions to voluntarily add and activiely participate, as individuals with self-control problems (self-control bias) are less likely to comprehensively plan for their retirement even if they are already financially disciplined. Furthermore, the results show that financial behavior, financial knowledge, and income significantly explain a members' likelihood of voluntarily comprehensively planning for retirement planning.

The policy implications of these findings is that as policy makers should not only focus on improving financial literacy through the financial education of basic financial concepts needed in financial decision-making but 
also incorporate pertinent issues that affect financial behaviour. The study therefore recommends that policymakers and pension scheme companies incorporate bahavioural change initiatives within their financial educational programs, making them practical to ensure members shift towards responsible financial behaviour that would enhance members' participation within the schemes and encourage them to participate comprehensively plan for their retirement.

Furthermore, the use of measures that inculcate self-control and avoid short-term gratification will also help improve retirement planning, the continual use of of passive automatic enrollment to pension schemes is an important device in simplifying decision-making for employees with bounded rationality and hence pension scheme regulations and laws enacted should take into consideration the fact that the populace at large exhibit self-control bias. Therefore policymakers not only need to advocate for automatic enrollment into the tier one pension scheme (NSSF) but also put in place modalities of increasing the amount of contribution in the NSSF to improve the replacement rate of scheme members upon retirement.

\section{References:}

1. Achtziger, A., Hubert, M., Kenning, P., Raab, G. and Reisch, L. (2015): 'Debt Out of Control: The Links Between Self-Control, Compulsive Buying, and Real Debts', Journal of Economic $\begin{array}{lllll}\text { Psychology. } & \text { Vol } & \text { 49, } & \text { Pp } & \text { 141-149. }\end{array}$ http://dx.doi.org/10.1016/j.joep.2015.04.003

2. Akben-Selcuk, E. (2015): 'Factors Influencing College Students' Financial Behaviors in Turkey: Evidence from a National Survey', International Journal of Economics and Finance, vol. 7, no. 6, pp 8694.

3. Baker, H.K. and Nofsinger, J. R. (2010): Behavioural Finance: Investors, corporations and Markets. John Wiley \& sons. DOI: $10.1002 / 9781118258415$.

4. Baker, H.K. and Ricciardi, V. (2014): Investor behavior: The psychology of financial planning and investing. John Wiley \& Sons. Doi.10.1002/9781118813454

5. Ballinger, T. P., Hudson, E., Karkoviata, L. and Wilcox, N. T. (2011): 'Saving Behaviour and cognitive abilities', Experimental Economics, Springer; Economic Science Association, vol. 14 no. 3, pp 349-374. DOI:10.1007/s10683-010-9271-3

6. Bartlette II, J. E. Kotrlik, J. W. and Higgins, C. C. (2001): 'Organisation Research: Determining appropriates sample size in survey research', Information Technology, Learning, and Performance Journal, vol. 19, no. 1, pp 43-50. 
7. Bijanavska, N and Palligkninis, S. (2015): 'Control thyself: Selfcontrol failure and household wealth', SAFE Working paper No. 69. Viewed on $2^{\text {nd }}$ April 2021, https://ssrn.com/abstract $=2509080$.

8. Choi, J. J., Laibson, D. and Madrain, B.C. (2011): ' $\$ 100$ bills on the sidewalk: Suboptimal investment in 401 (k) plans', The Review of Economics and Statistics, vol. 93, no. 3, pp 748-763

9. Financial Sector Regulators. (2020): The Kenya Financial Stability Report. October 2020. Issue no. 11. Financial Sector Regulators.

10. Gathergood, J. (2012): 'Self-control, financial literacy and consumer over-indebtedness', Journal of Economic Psychology, vol 33 no. 3 pp 590-602.

11. Githui, T. and Ngare, P. (2014): 'Financial Literacy and Retirement Planning in the Informal sector in Kenya', International Journal of Education and Research, vol 2.

12. Gutter, M. and Copur, Z. (2011): 'Financial Behaviors and Financial well-being of college students: Evidence from a national survey'. Journal of Family and Economic Issues, vol 32 no. 4, pp 699 714. DOI 10.1007/s10834-011-9255-2

13. Hastings, J. S. and Mitchell, O. S. (2011): 'How Financial Literacy and Impatience Shape Retirement Wealth and Investment Behaviors', NBER Working Paper No. 16740. JEL No. E21,G11,G23,H31,J26

14. Hede, P. (2012). Financial Decision making and Investor Behaviour.. Bookboon.

15. Hira, T. K., Rock, W. L and Loibl, C. (2009): 'Determinants of retirement planning behaviour and differences by age', International Journal of consumer studies. vol. 33. no 3 pp 293 - 301 DOI:10.1111/j.1470-6431.2009.00742.x

16. Howlett, E., Kees, J and Kemp, E. (2008): 'The Role of SelfRegulation, Future Orientation, and Financial Knowledge in Longterm Financial Decisions', The Journal of Consumer Affairs, vol 42, no. 2, pp 223-242.

17. International Organisation of Pensions Supervisors. (2018): IOPS country profile: Kenya. Paris

18. Kefela, G 2010, 'Promoting Access to Finance by Empowering Consumers - Financial Literacy in Developing Countries', Education Research Reviews, vol 5, no. 5, pp205 - 212.

19. Kenya National Bureau of Statistics. (2020) Economic survey 2020. Kenya National Bureau of Statistics.

20. Kim, K.T., Lee, J. M. and Hong, J. E. (2016): 'The role of Self-control on Retirement Preparedness of US Households', International Journal of Human Ecology, vol 17. no. 2. Pp 1-9. 
21. Lusardi, A. (2019): 'Financial literacy and the need for financial education: evidence and implications.' Lusardi Swiss Journal of Economics and Statistics, vol 155, no. 1 s (2019) DOI: 10.1186/s41937-019-0027-5.

22. Lusardi, A., and Mitchell, O. (2009). How ordinary consumers make complex economic decisions: Financial literacy and retirement readiness. NBER Working Paper NBER Working Paper No. 15350

23. Madrian, B. C., \& Shea, D. F. (2001): 'The Power of Suggestion: Inertia in 401(k) Participation and Savings Behavior', Quarterly Journal of Economics, vol CXVI no. 4, pp 1149-1187.

24. Moore, D. (2003): Survey of Financial Literacy in Washington State: Knowledge, Behavior, Attitudes, and Experiences. Social and Economic Sciences Research Center. Washington State University

25. Mudzingiri, C., Mwamba, J. W. M. and Keyser, N. J. (2018): 'Financial behavior, confidence, risk preferences and financial literacy of university students', Cogent Economics \& Finance Taylor \& Francis Journals, vol. 6 no. 1, pp 1512366-151. DOI: 10.1080/23322039.2018.1512366

26. O'Donoghue, T. and Rabin, M. (2001): 'Choice and Procrastination', The Quarterly Journal of Economics, vol. 116, no. 1 pp. 121-160. DOI: $10.1162 / 003355301556365$

27. Organisation for Economic Co-operation and Development. (2016): 'OECD/INFE International Survey of Adult Financial Literacy Competencies', OECD, Paris, viewed on $23^{\text {rd }}$ October 2017, www.oecd.org/finance/OECD-INFE-International-Survey-of-AdultFinancial-Literacy-Competencies.pdf

28. Pompian, M. (2006): Behavioral Finance and Wealth Management; How to Build Optimal Portfolios That Account for Investor Biases. John Wiley \& Sons, Inc,

29. Republic of Kenya. (2007): Vision 2030. Government Printer.

30. Retirement Benefits Authority. (2019): RBA Strategic Plan 2019 2024. RBA. Nairobi

31. Sabri, M. and MacDonald, M. (2010): 'Savings Behavior and Financial Problems Among College Students: The Role of Financial Literacy in Malaysia', Cross cultural Communication, vol 6, no. 3, pp103-110.

32. Shefrin, H. (2002): Beyond Greed and Fear: Understanding Behavioral Finance and the Psychology of Investing. Oxford University Press.

33. Shefrin, H. M. and Thaler, R. H. (1988): 'The behavioural life-cycle hypothesis', Economic Inquiry, vol 26, no.4, pp 609-643.

34. Strömbäck, C., Lind, T., Skagerlund, K.., Västfjäll, D. and Tinghög G. (2017): 'Does self-control predict financial behavior and financial 
well-being?' Journal of Behavioral and Experimental Finance, vol 14, pp 30-38

35. Sundindra V. R. and Naidu, J. G. (2018): 'Financial behavior and Decision making', International Journal of Creative Research Thoughts, vol 6, no.1, pp 1427-1435. DOI: 10.1729/IJCRT.17236

36. Thaler, R. H. and Benartzi, S. (2004): 'Save More Tomorrow: Using Behavioral Economics to Increase Employee Saving', Journal of Political Economy. vol. 112, no. S1, pp. S164-S187. DOI: 10.1086/380085

37. van Raaij, W. F. (2016): 'Responsible Financial Behavior', in Understanding Consumer Financial Behavior. Palgrave Macmillan, New York. pp 127-141 DOI: 10.1057/9781137544254_10

38. Were, M. (2011): 'Impact of Accessing Retirement Benefits before Retirement Age', Research Paper. RBA.

39. Xiao, J. J., Sorhaindo, B. and Garman, E. T. (2006): 'Financial behaviours of consumers in credit counseling', International Journal of Consumer Studies, vol 30, pp 108-121. 